\title{
HISTOPATHOLOGICAL CHANGES IN SARCOLEMMA AND SARCOPLASM IN COXSACKIE VIRUS INFECTION
}

\author{
BY
}

\author{
B. STRANDBERG \\ Rigshospitalets, Copenhagen, Denmark
}

(RECEIVED FOR PUBLICATION DECEMBER 7, 1954)

Between 1948 and 1950, Dalldorf and Sickles (1948), Dalldorf and others (1949), Dalldorf (1950), and Sickles and Dalldorf (1949) reported a previously unidentified virus in the faeces of children with the symptoms of acute anterior poliomyelitis. This virus has been named Coxsackie or C.-virus, and many authors (Magnus, 1949; Kaplan and Melnick, 1951; Melnick, 1947, 1950a, 1950b; Melnick and Godman, 1952; Melnick and Horstmann, 1947; Melnick and Kraft, 1950; Melnick and Ledinko, 1950; Melnick and various others, 1949, 1950a, 1950b) have contributed towards the elucidation of its epidemiology and serology. Moreover, in acute anterior poliomyelitis the virus could be shown in Bornholm disease (myalgia epidemica; Sylvest, 1933) and in certain forms of gastroenteritis.

Two reports on the symptomatology of pure Coxsackie virus infection appeared in 1950. Shaw and others (1950) described a laboratory infection in six assistants engaged on the isolation of C.-virus. The symptoms were raised temperature, feeling of general weakness, lack of appetite, pains in the throat, single instances with stiffness of the neck, and in some cases diarrhoea, and 2 days later pains localized in the muscles of the abdomen, thorax, and extremities. Hueber and others (1951) reported the appearance of an epidemic C.-virus infection. The C.-virus has since been isolated during epidemics in Switzerland (Thelin and Wirth, 1951), and during a typical outbreak of Bornholm disease in England and Scotland (Brown, Liddle, and Tobin, 1952; Davies and Warin, 1951).

Up till now, fourteen antigenically different strains of varying toxicity and tissue affinity have been isolated. One strain (Texas) has shown a decided affinity for the striated skeletal musculature and for the connective tissue.

The histopathological changes in the muscles during a C.-virus infection in mice were shortly described by Strandberg (1952) and were later reported by Godman and others (1952).
The present investigations have been carried out to ascertain whether the histopathological changes in the muscles in C.-virus infection are comparable with the muscular dystrophies of central origin (poliomyelitis, sclerosis lateralis amyotrophica, etc.) or with the genuine muscular dystrophies (polymyositis, dermatomyositis, dystrophia musculorum progressiva, etc.).

\section{Experiments}

In the State Serum Institute, Magnus carried out experiments with the C.-virus (Texas strain) administered to 188 albino mice in titres varying between $10^{-1}$ and $10^{-8}$. The mice were grouped according to age: $1,5,10$, 14,18 , and 21 days. Inoculations were given intraperitoneally in penicillin-streptomycin-saline solutions: $0.02 \mathrm{ml}$. to mice one day old, $0.03 \mathrm{ml}$. to all the others.

(1) 77 mice were inoculated during the first 5 days of life with virus titres varying between $10^{-1}$ and $10^{-8}$; the primary mortality was 100 per cent., and 22 per cent. died before developing paralysis.

(2) 41 mice were inoculated on the 10th day of life; the primary mortality was 95 per cent., and four mice died before developing paralysis.

(3) 28 mice were inoculated on the 14th day of life. Mortality due to infection was 50 per cent. Fourteen of the mice were inoculated with virus titres varying from $10^{-1}$ to $10^{-2}$, and ten died; the fourteen others were inoculated with virus titres varying between $10^{-3}$ and $10^{-4}$, and only four died. All the mice in this group had paralysis of one or more extremities.

(4) 42 mice were inoculated on either the 18 th or the 21 st day of life. All survived the infection, but only 7 per cent. developed paralysis of one or more extremities.

As a result of these experiments, the following groups of test animals were used:

(a) 22 mice inoculated at 14 days old with a solution of C.-virus, the titres varying between 10-3 and $10^{-4}$.

(b) Nineteen healthy controls.

Twelve of the infected mice were examined when 4 to 7 weeks old and the rest when 16 to 19 weeks old. All the infected animals had developed manifest paresis of one or both hind legs. 
Series of sections of infected and healthy gastrocnemius muscle were prepared in the Psychiatric Laboratory, University of Copenhagen. The tissues were sectioned at about $5 \mu$, and the preparations were stained with haematoxylin and eosin.

A number of these preparations were de-stained and de-paraffined, and used for studying the structural changes by polarization microscopy at the Neurophysiological Institute, University of Copenhagen.

\section{Results}

Appearances in Controls.-All preparations of the gastrocnemius muscles of the nineteen healthy controls showed approximately identical features. Longitudinal sections revealed fairly uniform thickness of fibres. Eosinophilic staining of the sarcoplasm was uniform. The myofibrils were poorly visible. The nuclei were spindle-shaped, homogeneous in structure, and situated immediately inside the sarcolemma.

The sarcolemma was of uniform thickness, investing the intact muscle fibre. There was no entry of round cells, and no oedema.

The cross sections correspondingly showed fairly uniform fibre diameters, and peripherally situated nuclei, with the sarcolemma tightly enclosing each muscle fibre. Polarization microscopy of the striated structure revealed normal cross striation of all longitudinally sectioned fibres (Fig. 1a).

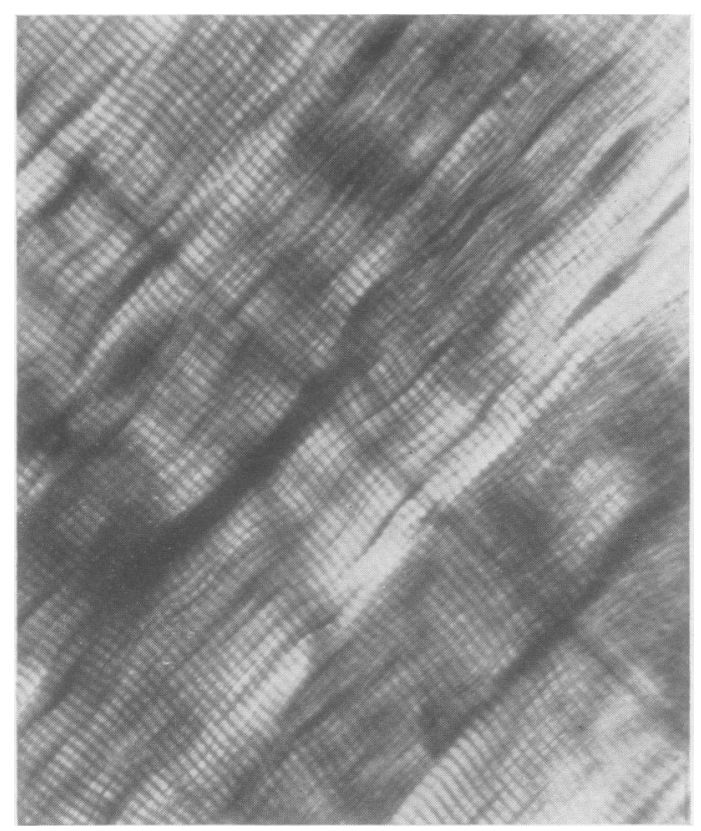

Fig. 1(a).-Cross-striated fibres of gastrocnemius muscle from healthy albino mouse. Longitudinal section, polarization microscope,
Variations in Cross Striation.-Pathological changes were ascertained in all preparations from the 22 mices. inoculated with C.-virus. On one preparation the striation was normal and well-defined; in the् remainder examined by polarization microscopy there was every variety of reduced definition of striation, until its complete disappearance (Fig. $1 b$ ) In some cases the character of the changes was diffuse, but in others the changed definition of striation was found within the individual fibres.

Variations in Muscle Fibre Diameters.-The preparations showed greater variation in the diameters of the muscle fibres in the C.-virus infected than in th: controls (Fig. 2, opposite). The maximum fibre. diameters were, therefore, measured (with the oculat micrometer) in 1,000 sections from ten healthy and ten infected mice. In the affected animals the diameters varied between 9 and $69 \mu$ (standard deviatio $\bar{P}$ $12 \cdot 4 \mu$; arithmetical mean value $33 \cdot 2 \mu$; standard error $0.3 \mu$ ). In the healthy animals, the correspond ing figures were 24 to $63 \mu$ (standard deviatio $7 \cdot 1 \mu$; average: $38 \cdot 5 \mu \pm 0 \cdot 2 \mu$ ).

The difference between the percentual distribution graphs shows that 43 per cent. of all measurement of preparations from animals infected with C.-virus were either higher or lower than those on preparas tions from healthy controls (Figs $3 a, b$ ). The average

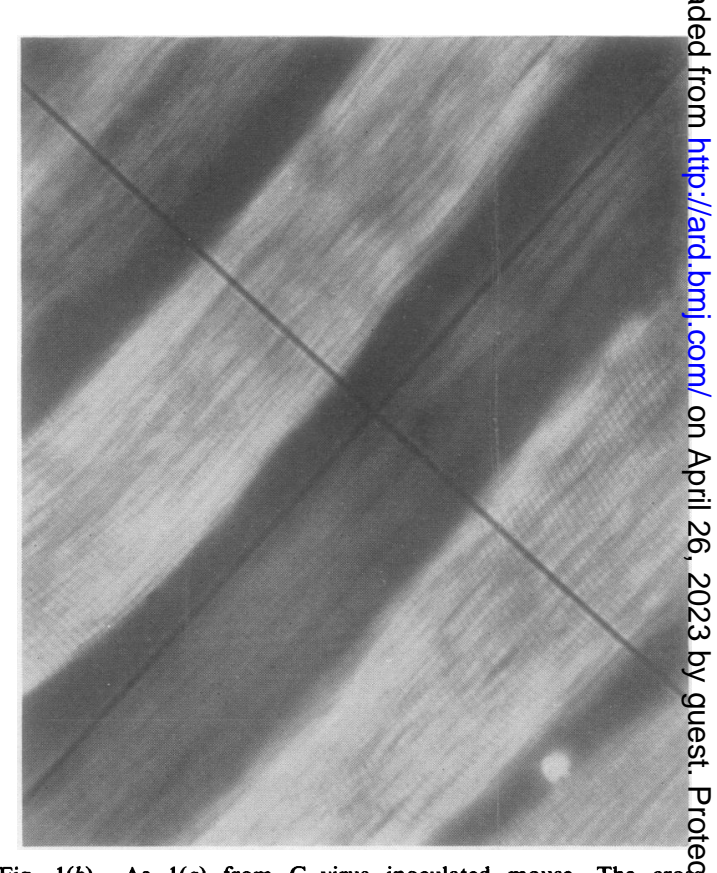

Fig. 1(b).-As 1(a) from C.-virus inoculated mouse. The cros striation is only faintly visible, and has completely disappeared some places. $\times 500$ $\times 500$. 


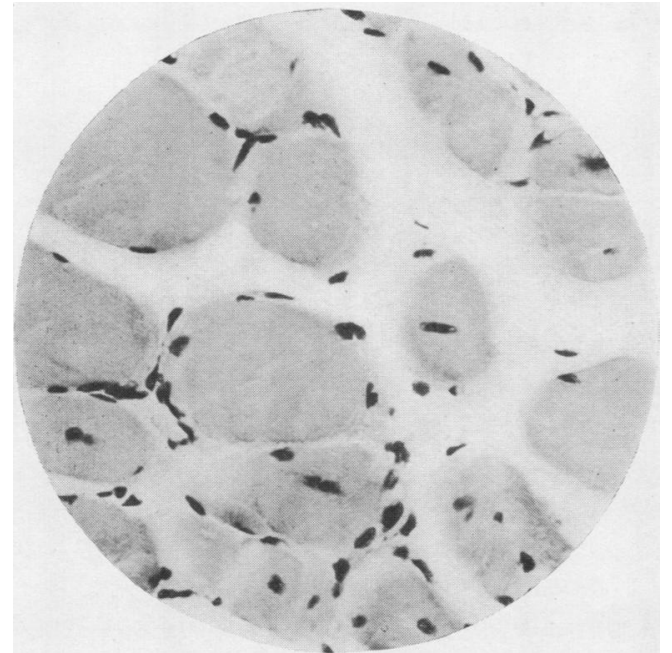

Fig. 2.-Fibres of gastrocnemius muscle from C.-virus inoculated mouse. Cross-section, $\times 400$. Note variations in size of fibres.

area of muscle fibre (expressed in terms of average radius in $\mu$ ) of 250 cross sections from ten infected and ten healthy mice revealed no difference between the two categories ( $17 \cdot 5 \mu$ and $17 \cdot 4 \mu$ respectively), whereas the standard deviation was considerably increased in the infected animals $(1 \cdot 4 \mu)$ as compared with the healthy controls $(0 \cdot 9 \mu)$.

\section{Histopathological Findings.}

Preparations of Cross-Sections of Fibres from C.-virus-infected Mice.-The fibres were oval or

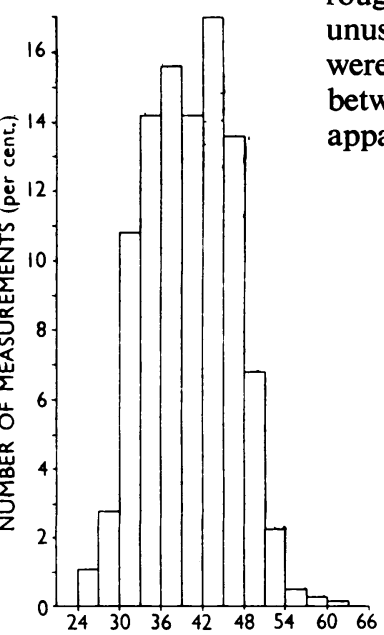

MUSCLE FIBRE DIAMETER $(\mu)$

Fig. 3(a).-Differences in size of fibre diameters (in $\mu$ ) from gastrocnemius muscle in a healthy control. (Standard deviation: $7 \cdot 1 \mu$.)

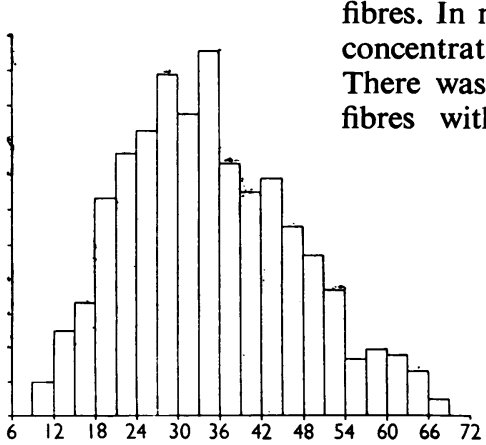
MUSCLE FIBRE DIAMETER $(\mu)$

Fig. 3(b).-Differences in size of fibre diameters $($ in $\mu$ ) from gastrocnemius muscle in C.virus inoculated mouse. (Standard deviation: $12 \cdot 4 \mu$.)

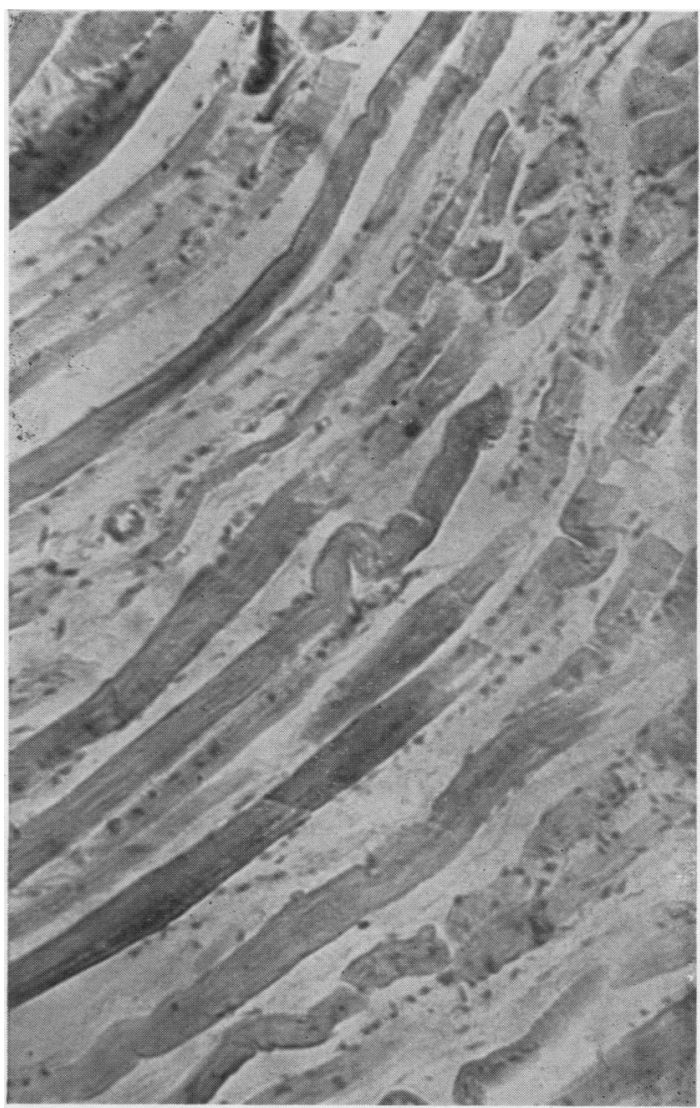

Fig. 4.-Longitudinal section of gastrocnemius muscle from C.-virus (Texas strain) inoculated mouse. Note deviation of some fibres from the normal longitudinal position with twisting and folding of the sarcoplasm; different fibres with different affinities to the stain, indicating the beginning of hyaline degeneration; slight perivascular and interstitial round cell infiltration; fragmentation of sarcoplasm within the sarcolemma sheath. $\times 100$.

fibres. In no instance was there a tendency towards concentration in patches of these atrophic fibres. There was a noticeable increase in the number of diameters greater and smaller than normal, and the hypertrophy of the individual fibres was greater than in the controls. This mixture of hypertrophic and atrophic fibres leads to the assumption that the virus attacks peripherally and not through the central nervous system.

Changes in Position (Fig. 4).--In all preparations a varying number of muscle fibres deviated from their longitudinal position. They twisted round the longitudinal axis, and the 


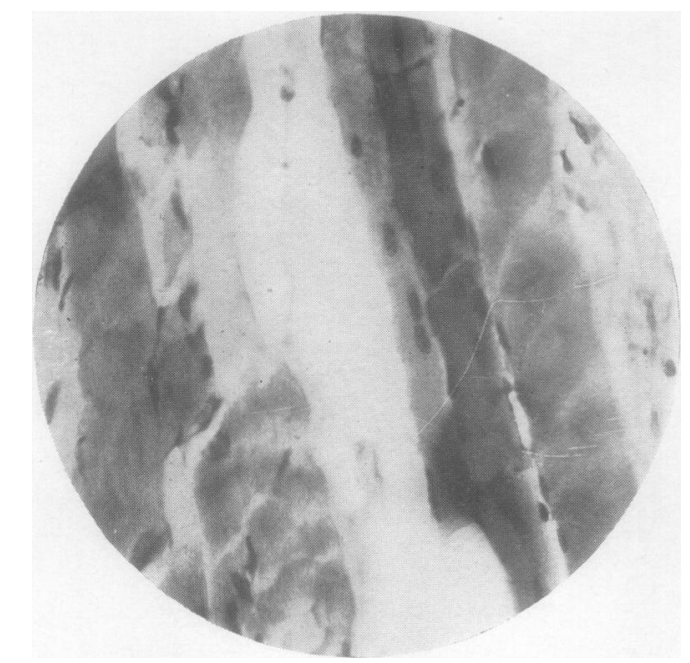

Fig. 5.-Longitudinal section of gastrocnemius muscle from C.-virus inoculated mouse. $\times 300$. Hyaline degeneration of fibres in different stages.

sarcoplasm was folded and twisted within the sarcolemma sheath. These folds tended to become isolated from the remaining sarcoplasm. The fragments sometimes consisted of normal sarcoplasm, but were formed in other instances from reticular or vacuolated sarcoplasm.

Longitudinal Division of Muscle Fibre into two or more smaller fibres was noticed in a number of preparations.

Concentric Division and Circular Formation did not occur.

Hyaline Degeneration.-Varying phases of hyaline degeneration to the point of calcification (Fig. 5) were observed in practically all the preparations and resembled the degenerations reported by Zenker.

It either appeared along the whole length of the fibre or was confined to definite areas within the individual fibre. The hyaline portions appeared either fissural or fractured.

Calcification.-There was pronounced calcification in four preparations from infected mice.

Changes in Myofibrils.--In some preparations the basophilic staining of the fibrils was above standard, and in others the structure was more or less blurred, and the well-defined myofibrils were situated like tight, thick, parallel, frequently wavy, lines along the whole length of the fibre. Inside a single fibre, the myofibrils were sometimes so strongly basophilically

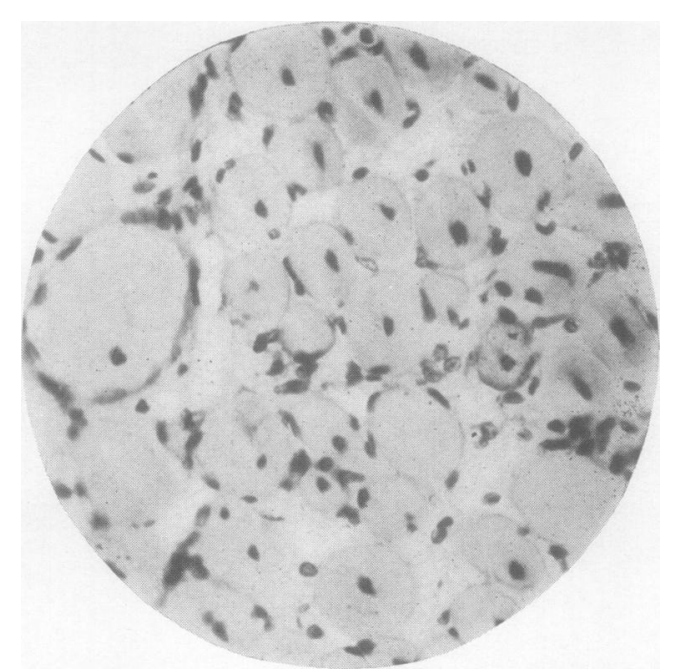

Fig. 6.-Cross-section of gastrocnemius muscle from C.-virus inoculated mouse. $\times 400$. Note variation in size of muscle fibr $\bar{S}$ diameters, nucleus in middle of fibre, sarcolemma sheath with varying thickness, and slight interstitial round-cell infiltration.

stained and coarsely delineated as to resemble calcification.

Changes in Muscle Cell Nuclei.-All preparationș from the infected mice showed an increased numbe 5 of muscle cell nuclei. Normal spindle-shaped homo geneous nuclei located inside the sarcolemma were observed, and more frequently circular of oval nuclei with a clearly visible nuclear membrane을 and nucleoli with strongly basophilic chromating particles. These circular nuclei were usually to be्e found centrally in slender basophilic muscle fibreș (Fig. 6). The nuclei lay in long chains of up to thirtye in each fibril (Fig. 7). At one end of the row, the nuclei were tightly congested during amitotic-. division, and increasing distances between the nuclei represented the transition to normal muscle cell nuclei. In single cases mitotic division or states of pyknotic and karyorrhectic degeneration weres noticed.

Changes in Sarcolemma.-The most pronounced $\stackrel{N}{P}$ changes took the form of an increase in the number of sarcolemma nuclei, and varying thickness of sarcolemma. Frequently the sarcolemma was intacto and empty sarcolemma sheaths might be observes without tendency to collapse. In some cases, the sarcolemma was abnormally thick, and in others it? was atrophic, permitting the entry of the interstitiaito round cells.

Ingress by Interstitial Round Cells.-This was observed in all preparations. The invasions were 


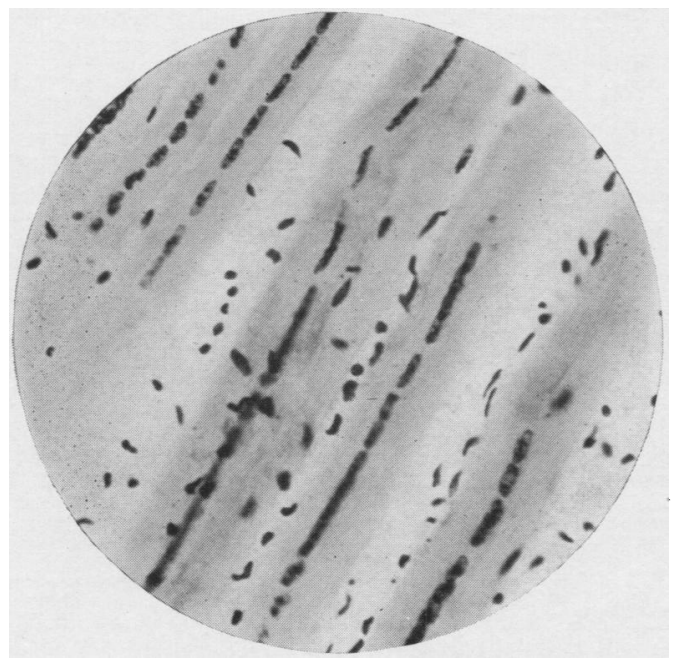

Fig. 7.-Longitudinal section of gastrocnemius muscle from C.-virus inoculated mouse. $\times 400$. Note regeneration of muscle fibres, with slight affinity to stain, and nuclei arranged in longitudinal chains after amitotic division in centre of fibre.

perivascular, interstitial, and interfibrillar (Fig. 8). In young mice, the perivascular invasion seemed to be more frequent and more massive than the interstitial form.

Oedema.-This was pronounced in nearly all the preparations.

Hyperplasia of Lymph Nodes.-In a number of preparations hyperplasia of solitary interstitial nodes was seen.

\section{Summary of Histopathological Findings}

The histopathological changes observed may be divided into three aetiologically different groups:
(a) degenerative,
(b) inflammatory,
(c) regenerative.

(a) Degenerative Changes.-These manifest themselves in the muscle fibres with a tendency to abandon their longitudinal growth: the fibre twisting and folding within the sarcolemma sheath.

The fibre thus coiled or twisted then becomes "laced off" tending to degenerate piecemeal. Changes in the structure of the sarcoplasm are observed in the form of vacuolation and dissolution, during which the sarcoplasm presents a reticular structure. Furthermore, the entire fibre may be homogeneously transformed through a process of hyalinosis that in extreme cases may continue into calcification. During the process the striated structure disappears, either in certain parts or along the whole fibre.

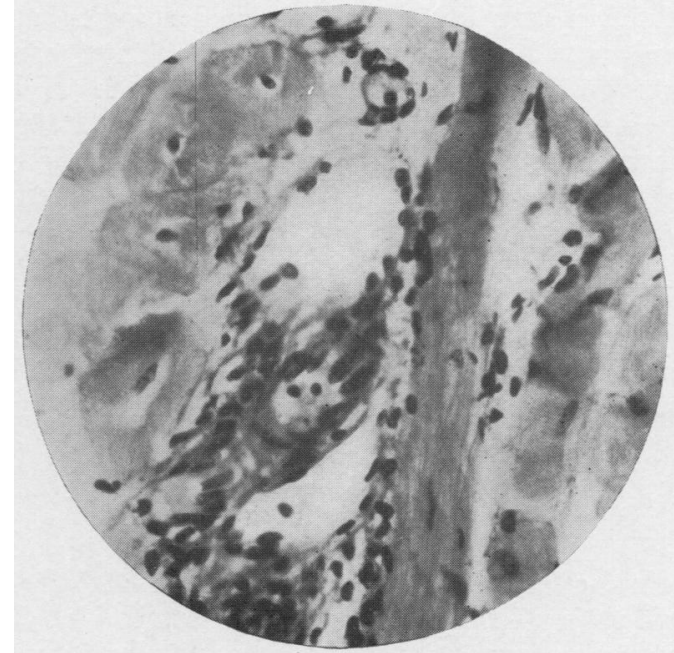

Fig. 8.-Perivascular infiltration of round cells.

Generally, more or less pronounced longitudinal striation appears, the myofibrils becoming coarser and the basophilic staining stronger with tendency to fusion; in pronounced instances the myofibrils appear as longitudinal calcified streaks along the muscle fibre. Simultaneously changes occur in the nuclei which may become pyknotic and undergo karyorrhexis and karyolysis. These changes frequently take place within the intact sarcolemma, but sometimes the sarcolemma is damaged leaving a space through which an invasion of round cells may occur.

(b) Inflammatory Changes.-These may occur as interstitial oedema as well as round cell invasion, which entails increased numbers of histiocytes, lymphocytes, polymorphonuclear leucocytes, and mononuclear phagocytes. The invasion may be perivascular, interstitial, or interfibrillar. Hyperplasia of the regional lymph nodes may also occur.

(c) Regenerative Changes.-These comprise formation of hypertrophic fibres, increased appearance of longitudinal division of remaining healthy muscle fibres, or stretching and growth of the non-affected parts of a muscle fibre. Amitotic divisions of muscle cell nuclei arrange themselves in long chains around which develop basophil sarcoplasm, out of which myofibrils and, later, cross striations, differentiate. These fibres are more slender than those normally found, and they all have centrally arranged chains of nuclei.

The basophilism of the muscle fibres decreases with the formation of the myofibrils and the striated structure; the nuclei take up more peripheral 
positions and become oblong and spindle-shaped and more homogeneous in structure. The amitotic division may frequently begin in a muscle cell nucleus surrounded by partly degenerated sarcoplasm. This nucleus and the new chain of nuclei may sometimes be connected through thin cytoplasmic cords.

These regenerative processes are rarely to be observed in their pure form. The average picture shows a confusion of degenerative, inflammatory, and regenerative processes, all stages of these three phases being seen within the individual muscle fibre.

\section{Discussion}

The histopathological changes found in these examinations confirm the observations of Melnick and others. They reveal no point of similarity to the changes appearing after infection by the virus of acute anterior poliomyelitis or in the muscles of a patient suffering from muscular dystrophies of spinal or neurological origin (Wohlfahrt and Wohlfart, 1935, 1936).

The lesions correspond on the other hand with what might be found in polymyositis (Christensen and Levison, 1950): inflammatory infiltration into the interstitial connective tissue and muscle fibres by polymorphonuclear leucocytes, lymphocytes, plasma cells, and histiocytes. The infiltrations were perivascular as well as diffuse. The muscle fibres showed irregular atrophy as in dystrophy of peripheral muscular origin. These changes also correspond to those found by Levison (1951) in biopsies from patients suffering from progressive muscular dystrophy.

The arrangement of the atrophic and hypertrophic fibres makes it believable that $\mathrm{C}$.-virus infectionso far as it concerns muscle tissues-gives rise to a genuine muscular dystrophy. This leads to the question whether the changes ascertained in the last-mentioned group may be considered as more or less chronic manifestations of a previous virus infection.

\section{Summary}

Microscopic examinations of the gastrocnemius muscles of 22 albino mice inoculated with Coxsackie virus (Texas strain) were carried out. Nineteen healthy animals served as controls. The reaction to Coxsackie virus infection took the form of pronounced myositis.

Examinations by polarization microscopy revealed reduction and final complete disappearance of cross striation in the muscle fibres. These changes may affect the entire fibre, or certain areas only.
Pronounced degenerative, inflammatory, and regenerative changes were observed.

The dominant features of degeneration were? sarcolysis, degeneration of the contractile parts of the sarcoplasm, degeneration of nuclei accompanied by pyknosis, karyolysis and karyorrhexis, dissolution and hyalinosis of the sarcoplasm, calcification, and phagocytosis.

Inflammation took the form of perivascular interstitial, and interfibrillary changes, with invasion ${ }^{\infty}$ of inflammatory cells.

Regenerative changes appeared partly as amitotic division of muscle cell nuclei resembling sarcoplasts, $\omega$ and partly as increased longitudinal division of theo sarcoplasm, besides proliferation and hypertrophy? of non-affected sarcoplasm.

The histopathological changes observed make it $-\dot{\omega}$ likely that mice infected with Coxsackie virus reactor by developing genuine muscular dystrophy.

These studies were carried out with the co-operationo of the Psychiatric Laboratory, University of Copenhagen (Dr. E. Christensen); the Neurophysiological Institute, University of Copenhagen (Dr. F. Buchthal); the State of Serum Institute, Virus Department, Copenhagen (Dr. + Herdis von Magnus); and the Military Hospital, Department of Physical Medicine and Rheumatic Diseases, Copenhagen (Dr. K. Jespersen).

\section{REFERENCES}

Brown, C. Metcalfe, Liddle, D. C., and Tobin, J. O'H. (1952). $\overrightarrow{\widehat{O}}$ Lancet, 1, 445 .

Christensen, E., and Levison, H. (1950). Acta psychiatr. neurol., 25, 137.

Dalldorf, G. (1950). Bull. N.Y. Acad. Med., 26, 329.

, and Sickles, G. M. (1948). Science, 108, 61 .

,, Plager, H., and Gifford, R. (1949). J. exp. Med., 89, 567.

Davies, J. B. M., and Warin, J. F. (1951). Brit. med. J., 2, 948 .

Godman, G. C., Bunting, H., and Melnick, J. L. (1952). Amer.

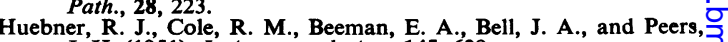
J.' H. (1951). J. Amer. med. Ass., 145, 628.

Kaplan, A. S., and Melnick, J. L. (1951). Proc. exp. Med., 76, 312.

Levison, H. (1951). Acta psychiat. neurol. scand., Suppl. 76.

Levison, P. (1937). Ibid., 12, 89.

Magnus, H. von (1949). Ugeskr. laeg., 111, 145.

Melnick, J. L. (1947). Amer. J. Hyg., 45, 240.

- (1950a). Bull. N.Y. Acad. Med., 26, 342. (1950b). Bact. Rev., 14, 233.

Clarke, N. A., and Kraft, L. N. (1950), J.exp. Med. 92, 499.

-, Clarke, N. A., and Kraft, L. "N. (1950). J. exp. Med., 92, 499. Society on 26 Oct., 1950". Proc. N.Y. path. Soc. (1950-1951), N p. 54 .

and Horstmann, D. M. (1947). J. exp. Med., 85, 287

, and Kraft, L. M. (1950). Fed. Proc., 9, 585. and Ledinko, N. (1950). J. Immunol., 64, 101. 91,185

- 91, 185 . Whaw, E. W., and Curnen, E. C. (1949). Proc. Soc. exp. Biol (N.Y.), 71, 344. Shaw, E. W., Melnick, J. L., and Curnen, E. C. (1950). Ann. intern.

Sickles, G. M., and Dalldorf, G. (1949). Proc. Soc. exp. Biol. (N.Y.), $72,30$.

Strandberg, B. (1952). "Poliomyelitis", p. 516. Lippincott, London. T Sylvest, E. (1933). "Den Bornholmske Syge". Copenhagen. English ranslation (1934). "Epidemic Myalgia-Bornholm Disease". Oxford University Press.

Thélin, G., and Wirth, J. (1951). Rev. Med. Suisse Romade, 71, 44. Wohlfahrt, S., and Wohifart, G. (1935). Acta med. scand., Suppl. 63. W. - (1936). Nord. med., 11, 244. 
Altérations histologiques dans le sarcolemme et le sarcoplasma au 'cours de l'infection par le virus de Coxsackie

\section{RÉSUMÉ}

On examina microscopiquement le muscle gastrocnémien des 22 souris blanches infectées de virus de Coxsackie (souche de Texas). Dix-neuf animaux sains servirent de témoins. La réaction à l'infection par le virus de Coxsackie prit la forme d'une myosite prononcée.

L'examne au microscope polarisant révéla la réduction et finalement la disparition des stries croisées des fibres musculaires. Ces altérations portèrent sur la fibre entière ou bien sur des portions de celle-ci seulement.

On observa des réactions de dégénérescence, inflammatoires et régénératrices.

Parmi les traits principaux de la dégénérescence on cite: sarcolyse, dégénérescence des parties contractiles du sarcoplasma, dégénérescence des noyaux accompagnée de pycnose, caryolyse et caryorrhexie, fonte et dégénérescence hyaline du sarcoplasma, calcification et phagocytose.

L'inflammation se traduisit par des altérations périvasculaires, interstitielles et interfibrillaires avec invasion des cellules inflammatoires.

La régénération se manifesta sous forme de la division amitotique des noyaux des cellules musculaires ressemblant à des sarcoplastes, et aussi de la scission longitudinale augmentée du sarcoplasma, à coté de la prolifération et de l'hypertrophie du sarcoplasma sain.

Les altérations histopathologiques observées viennent à l'appui de l'hypothèse montrant que les souris infectées de virus de Coxsackie réagissent par une véritable dystrophie musculaire.
Alteraciones histológicas en el sarcolema y el sarcoplasma en el curso de la infección por el virus de Coxsackie

\section{SUMARIO}

Se examinó microscopicamente el músculo gastrocnemio de 22 ratones blancos inoculados con el virus de Coxsackie (cepa de Texas), con 19 animales sanos como testigos. La reacción a la infección por el virus de Coxsackie tomó la forma de una miositis pronunciada.

El examen al microscopio polarizante mostró la reducción y finalmente la desaparición de la estriadura cruzada de las fibras musculares. Estas alteraciones afectaron sea las fibras enteras sea ciertas de sus porciones.

Observáronse reacciones de degeneración, inflamatorias y regeneradoras.

Los rasgos dominantes de la degeneración fueron: sarcolisis, degeneración de las partes contractiles del sarcoplasma, degeneración de los núcleos con picnosis, cariolisis y cariorexia, disolución e hialinosis del sarcoplasma, calcificación y fagocitosis.

$\mathrm{La}$ inflamación tradújose por alteraciones perivasculares, intersticiales e interfibrilares con invasión de células inflamatorias.

La regeneración tomó la forma de división amitótica de los núcleos de las células musculares que se parecían a sarcoplastos $y$, en parte, de división longitudinal aumentada del sarcoplasma, al lado de la proliferación e hipertrofía del sarcoplasma sano.

Las alteraciones histológicas observadas ofrecen la probabilidad de que los ratones infectados con el virus de Coxsackie reaccionan con una verdadera distrofia muscular. 